\title{
Making quick decisions: an investigation on the relationship between multiple tasks and impulsiveness
}

\author{
Toma de decisiones rápidas: investigación de la relación entre múltiples tareas \\ e impulsividad
}

Tomada de decisões rápidas: investigação da relação entre múltiplas tarefas e impulsividade

\author{
Valéria Marcondes Pereira, Doctor \\ Air Force Academy - AFA \\ Pirassununga/SP - Brazil \\ valeria_afa@yahoo.com.br
}

Luiz Maurício de Andrade da Silva, Doctor Air Force Academy - AFA Pirassununga/SP - Brazil Ima28@uol.com.br

\begin{abstract}
This article is part of a research project that aims at contributing to the training of military pilots, specifically training for quick decisions. The starting point of the research is the aptitude test for military flying (TAPMIL), which assesses the candidate's learning potential for military flying, with a view to flight instruction performed in the Air Instruction Squadrons of the Air Force Academy (AFA). It is a fully computerized psychological test, comprised of a battery of six tests that assess, either alone or in a combined manner, inherent flying skills, such as the "cognitive capacities" (e.g., information processing, speed and accuracy of responses, working memory) and the ability to "multitask" (psychomotor and cognitive combined) (COSTA, 2010, p. 6). Evidence are sought for assigning weights to the different variables intervening in the aptitude problem (SILVA et al., 2009), which brings us to choose - to date - as a featured variable, the ability to run multiple tasks. The focus in the "multitask" variable led us to new investigative lines, such as studies on human judgment in decisions, particularly those taken in dynamic environments and of great uncertainty (KLEIN, 2009), and the correlation between the ability to perform multiple tasks and impulsiveness. In order to continue this investigative line about the correlation between multiple tasks and impulsiveness, this study aims at presenting the results of two tests performed with the Brazilian Air Force cadets, aviators from the class of 2011 , a total of 60 (sixty) volunteers. To verify the ability to multitask, the "all at once" test was used (HERCULANO-HOUZEL, 2014). For the impulsiveness test, 45 (fortyfive) volunteers used the Barratt Impulsiveness Scale - BIS 11.
\end{abstract}

Keywords: Multitasking. Impulsiveness. Decision-making. Performance.

Received / Recibido / Recebido 09/22/14
Accepted / Aceptado / Aceito

$05 / 22 / 15$ 


\section{RESUMEN}

Este artículo forma parte de un proyecto de investigación que tiene el objetivo de contribuir con el entrenamiento de pilotos militares, específicamente con el entrenamiento para decisiones rápidas. El punto de partida de la investigación es la prueba de aptitud para pilotaje militar (TAPMIL), que evalúa el potencial de aprendizaje del candidato para el pilotaje militar, con el objetivo de instrucción de vuelo realizada en los Escuadrones de Instrucción Aérea de la Academia de la Fuerza Aérea (AFA). Es un una prueba psicológica totalmente informatizada, compuesta por una batería de seis testes que evalúan, de manera aislada o combinada, aptitudes inherentes al pilotaje, como "capacidades cognitivas" (por ejemplo, procesamiento de información, velocidad y precisión de respuestas, memoria de trabajo) y capacidad en "tareas múltiples" (psicomotoras y cognitivas combinadas) (COSTA, 2010, p. 6). Se buscan evidencias para atribuir pesos a las diferentes variables intervinientes en el problema de la aptitud (SILVA et al., 2009), lo que nos remite a elegir - hasta el presente momento - como variable de destaque, la capacidad de ejecución de múltiples tareas. El foco, en la variable 'múltiples tareas', nos llevó a nuevas líneas investigativas, como estudios sobre el juicio humano en decisiones, sobre todo aquellas tomadas en ambientes dinámicos y de gran incertidumbre (KLEIN, 2009), y la correlación existente entre la capacidad de ejecutar múltiples tareas y la impulsividad. Pretendiendo continuar esa línea investigativa a respecto de la correlación existente entre múltiples tareas e impulsividad, el presente trabajo tiene como objetivo presentar los resultados de dos testes realizados con los cadetes de la Fuerza Aérea Brasileña, aviadores del grupo de 2011, en un total de 60 voluntarios. Para verificar la capacidad de ejecutar múltiples tareas, e utilizó la prueba "todo al mismo tiempo" (HERCULANO-HOUZEL, 2014). Para la prueba de impulsividad, con 45 (cuarenta y cinco) voluntarios, se usó la Escala de Impulsividad de Barratt - BIS 11.

Palabras clave: Múltiples tareas. Impulsividad. Tomada de decisión. Desempeño.

\section{RESUMO}

Este artigo é parte de um projeto de pesquisa que tem o objetivo de contribuir com o treinamento de pilotos militares, especificamente com o treinamento para decisões rápidas. O ponto de partida da pesquisa é o teste de aptidão para pilotagem militar (TAPMIL), que avalia o potencial de aprendizagem do candidato para a pilotagem militar, com vistas à instrução de voo realizada nos Esquadrões de Instrução Aérea da Academia da Força Aérea (AFA). É um teste psicológico totalmente informatizado, composto por uma bateria de seis testes que avaliam, de maneira isolada ou combinada, aptidões inerentes à pilotagem, como "capacidades cognitivas" (por exemplo, processamento de informação, velocidade e precisão de respostas, memória de trabalho) e capacidade em "tarefas múltiplas" (psicomotoras e cognitivas combinadas) (COSTA, 2010, p. 6). Buscam-se evidências para a atribuição de pesos para as diferentes variáveis intervenientes no problema da aptidão (SILVA et al., 2009), o que nos remete a eleger - até o presente momento - como variável de destaque, a capacidade em execução de múltiplas tarefas. O foco, na variável 'múltiplas tarefas', levou-nos a novas linhas investigativas, como estudos sobre o julgamento humano em decisões, sobretudo aquelas tomadas em ambientes dinâmicos e de grande incerteza (KLEIN, 2009), e a correlação existente entre a capacidade de executar múltiplas tarefas e a impulsividade. Com vistas a continuar essa linha investigativa a respeito da correlação existente entre múltiplas tarefas e impulsividade, o presente trabalho tem por objetivo apresentar os resultados de dois testes realizados com os cadetes da Força Aérea Brasileira, aviadores da turma de 2011, em um total de 60 voluntários. Para a verificação da capacidade de executar múltiplas tarefas, utilizou-se o teste "tudo ao mesmo tempo" (HERCULANOHOUZEL, 2014). Para o teste da impulsividade, com 45 (quarenta e cinco) voluntários, utilizou-se a Escala de Impulsividade de Barratt - BIS 11.

Palavras-chave: Múltiplas tarefas. Impulsividade. Tomada de decisão. Desempenho.

\section{INTRODUCTION}

Man, as a social being, is complex in its entirety. There are influences on the relationship between individual and organization, and the manager must take into account the analysis of the individual in particular and collectivity in the organizational environment.

Behavioral disinhibition constitutes a personal control inability to respond to the demands of the situation. Failure, in behavioral inhibition, has been receiving the designation of impulsiveness in literature.
The purpose of this study is to investigate the relationship between multitasking and impulsiveness. There are reports in literature that those who consider themselves fittest to perform multiple tasks are precisely the most impulsive of all (SABONMATSU et al., 2013). Thus, we intend to check whether it happens in a sample of cadets from the Brazilian Air Force Academy.

Human behavior studies, from the perspective of neuroscience, are based on the following principle: "what we are, do, think and desire is the result of the workings of the nervous system and its interaction 
with the body." Neuroscience seeks to understand the relationship of the structure and workings of the nervous system with the life story of each person; culture, society, and genetics make us what we are, individually, as human beings and as animals (HERCULANO-HOUZEL, 2014).

\section{THEORETICAL FRAME OF REFERENCE}

The theoretical references develop under the themes of organizational cognition and quick decisions.

\subsection{Organizational cognition}

With respect to cognition, there is a plurality of languages and concepts that permeate this field of research. Among the aspects shown in the studies of Davel and Vergara (2001), we have the first of them with the confirmatory display of disruption of the Cartesian mind concept, namely, the mind is completely separate from the physical body. That means breaking away from the reason-and-emotion dichotomy and start to see the man as a whole, linking the cognitive and emotional processes of the body, which are considered central to rationality.

Labeled as constructivist, the second branch has the man as the subject of the story, not just a spectator. Enunciated by Davel and Vergara (2001), the mind as an active tool in the building of the world becomes a specific area of research in social psychology, according to which the social nature of cognition processes go beyond simple information processing.
Bureaucratic organizations consolidate themselves with the macro-oriented perspective in organizational studies, based on sociology, political science and economics. According to Hall,

\begin{abstract}
the macro look in organizational studies departs from the behavior of people and is due to organizational factors. Organizations have the power to shape be havior and individual actions. They act, have policies, make statements. They subsist in time beyond the people who comprise it. There is a social structure, a system of rules, norms, values and expectations that pre-exist individuals. (HALL, 1984 apud DAVEL; VERGARA, 2001 , p. 96 , our translation).
\end{abstract}

Organizations, whose influence is a micro-oriented perspective, are grounded in psychology. Its root is the dynamics of human relations, which deals with the concept of organization as something apart from the interaction of individuals. As opposed to the previous view, in the determining role of the organization on individual processes, this perspective emphasizes more the individual's role in building the organization. According to Staw and Sutton,

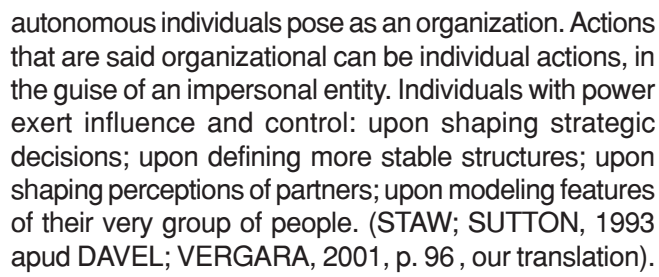

Chart 1 shows an evolution of cognitive approaches starting from the 1990's.

Chart 1 - Cognitive approaches.

\begin{tabular}{|c|l|}
\hline Authors & \multicolumn{1}{c|}{ Cognitive approaches } \\
\hline \multirow{3}{*}{ Wilpert (1995) } & $\begin{array}{l}\text { Signals the growth of the symbolic and constructive perspective. } \\
\text { Claims to be unnecessary the conflict between macro and micro-oriented approaches. } \\
\text { Addresses the organizational phenomenon as socially constructed through the interaction of } \\
\text { relevant authors. }\end{array}$ \\
\hline \multirow{2}{*}{ Rousseau (1997) } & $\begin{array}{l}\text { The organization is seen as a "process" rather than an "entity." } \\
\text { Organization as a social construction. }\end{array}$ \\
\hline \multirow{3}{*}{ Angelmar (1993) } & $\begin{array}{l}\text { Articulate three levels of analysis (individual, group and organization) and three core properties } \\
\text { of cognition: } \\
\text { - cognitive structures (how knowledge is acquired and used); } \\
\text { - cognitive processes (how knowledge is acquired and used); and } \\
\text { - cognitive styles (how units are distinguished as to structures and knowledge processes). }\end{array}$ \\
\hline \multirow{2}{*}{ Walsh (1995) } & $\begin{array}{l}\text { Cognitive studies have focused on four levels of analysis (individual, group, organization, industry) and } \\
\text { cognitive issues (representation, use and development of "knowledge structures"). The development } \\
\text { and changes in knowledge structures; the representation or the "knowledge structure" itself, seeking } \\
\text { to discover, in the face of specific structures used by managers, their attributes, specific contents and } \\
\text { how these are structured; and the use and consequences of these structures, namely, their impact on } \\
\text { organizational results at different levels. }\end{array}$ \\
\hline
\end{tabular}

Reference: Adapted from Davel and Vergara (2001). 
Thus, Davel and Vergara (2001) highlight some striking features about the state-of-the-art in the field of cognition and organization.

Studies on organizational cognition are aimed at exploring the impacts of knowledge structures on the lives of people, managers and organizations. On the other hand, a small number of researches involving automatic processing, uncontrolled or unconscious is found.

Approaches that integrate cognitive structures and cognitive processes are rare. And yet, the assumption that individual cognition produces organizational behavior that can lead to the understanding of collective processes as sums of individual processes is strong. This relationship requires justification of the act that is stressed after its occurrence.

Whatever perspective consolidates the organization, on a micro or macro side, there are individuals and processes taking place in the organization. These processes culminate in what is conventionally called decisions.

\subsection{Types of decisions}

Although the art of war and military movements have influenced some branches of theoretical research regarding decisions, such as operational research and logistics, major advances have occurred within private organizations of economic interest. Traditionally, these organizations divide decisions into two main blocks: strategic decisions, and operational and tactical decisions.

In the group of strategic decisions, the focus is always the widest time horizon and attention to the impact that such decisions can produce in the competition arena between organizations. In the group of operational and tactical decisions, the horizon becomes shorter and attention turns back to the efficiency and productivity of operations.

With the advent of behavioral economics, new actors began to investigate decisions - now with greater focus on human behavior - from the perspective of cognitive psychology. As a result, decisions began to be analyzed under a new look (or block): (i) rational decisions, taken in planned situations involving low-risk bets in lowpressure environments in terms of decision time, and supported mainly in mathematics and postulates of logic; and (ii) intuitive decisions taken in dynamic situations, in shortage of decision time, and with little use of the logic deliberation resource.

In short, structured and quick decisions. Quick decisions, of a more intuitive character, were classified as decisions based on system 1 of thought and deliberations. Structured decisions, in turn, were classified as decisions based on system 2 of thought and deliberations (BAZERMAN, 2006).

Thus, it was agreed upon that type 1 decisions would be more dependent on the repertoire of individual experiences, which would enable the decision maker to better use their sense of circumstantiality and subjectivity, and type 2 decisions would be more dependent on the use of mathematical and instrumental logic. In military piloting, depending on each situation and flight stage, decisions by pilots may require one system or the other, or even a combination of both thinking and decision.

In the scope of this work, the interest falls upon the quicker decisions in a dynamic environment, like the one that characterizes flying. Another reason for the lighting of the issues related to faster and more intuitive decisions is justified by the central theme of this work, which explores the characteristics of impulsivity when managing multiple tasks.

\section{METHODOLOGY}

As already stated, the purpose of this study is to verify that, in a sample of Air Force Academy cadets, the ability to manage multiple tasks is correlated with the impulsiveness of these young people. The survey included a total of 45 (forty- five) volunteers $(\mathrm{N}=45)$.

To verify the ability to manage multiple tasks, we used two instruments: the TAPMIL software and the "all at once" (TMT) game, which was made available by a team of neuroscientists coordinated by Suzana Herculano-Houzel. In this game, whose goal is to obtain the highest number of points and consequently control a greater number of tasks, tasks are gradually increased as the player moves from stage to stage.

For verification of impulsiveness, the BIS-11 tool was applied, which uses the Barratt Impulsiveness Scale - BIS 11. This instrument consists of 30 (thirty) questions, in which only one of the following alternatives is marked by the respondent: (1) rarely or never; (2) from time to time; (3) frequently; (4) almost always or always. The tabulation of data followed the score for questions ranging from 1 to $4(1,2,3,4)$. In questions $1,7,8,9,10,12,13,15,20$, 29 and 30, the reverse order was considered $(4,3,2,1)$.

Despite cultural differences related to concepts relating to different kinds of impulsiveness, the Barratt BIS 11 model has been successfully adapted to different cultures, evidencing its cross-cultural validity. Given the importance of the model proposed by Barratt - BIS 11 for studies on impulsiveness, it is considered that the development of a Brazilian version of the scale is very important for clinical practice and for carrying out studies on the subject (MALLOY-DINIZ et al., 2010, p. 104).

Patton et al. (1995) define the current version of the instrument carried out by a main component analysis in BIS-11. The scores collected from a sample of 248 (two hundred and forty-eight) psychiatric inpatients and 412 (four hundred and twelve) college students. Factor analysis from these cases revealed three secondorder factors, herein called secondary, and six firstorder oblique factors, or primary. Chart 2 shows the relationship between the first and the second order, as well as BIS-11 questions in the factors. 
Chart 2 - Primary and secondary factors of BIS 11.

\begin{tabular}{|c|c|c|c|c|}
\hline \multicolumn{5}{|c|}{ Barratt Impulsiveness Scale - BIS 11} \\
\hline Secondary factors & & Primary factors & $\begin{array}{l}\text { No. of } \\
\text { items }\end{array}$ & $\begin{array}{l}\text { Items that contribute to each } \\
\text { subscale }\end{array}$ \\
\hline \multirow{2}{*}{$\begin{array}{l}\text { Attention } \\
\text { impulsiveness }\end{array}$} & \multirow{2}{*}{$\begin{array}{l}\text { Impulsiveness related to quick decision- } \\
\text { making }\end{array}$} & Attention & 5 & $5,9 *, 11,20 *, 28$ \\
\hline & & $\begin{array}{l}\text { Cognitive } \\
\text { instability }\end{array}$ & 3 & $6,24,26$ \\
\hline \multirow{2}{*}{$\begin{array}{l}\text { Motor } \\
\text { impulsiveness }\end{array}$} & \multirow{2}{*}{$\begin{array}{l}\text { Motor impulsiveness is related to the } \\
\text { non-inhibition of responses incoherent } \\
\text { with the context }\end{array}$} & Motor & 7 & $2,3,4,17,19,22,25$ \\
\hline & & Perseverance & 4 & $16,21,23,30^{*}$ \\
\hline \multirow{2}{*}{$\begin{array}{l}\text { Impulsiveness by } \\
\text { non-planning }\end{array}$} & \multirow{2}{*}{$\begin{array}{l}\text { Encompasses behaviors oriented } \\
\text { towards the present }\end{array}$} & Self-control & 6 & $1^{*}, 7^{*}, 8^{*}, 12^{*}, 13^{*}, 14$ \\
\hline & & $\begin{array}{l}\text { Cognitive } \\
\text { complexity }\end{array}$ & 5 & $10^{*}, 15^{*}, 18,27,29 *$ \\
\hline
\end{tabular}

Reference: The author.

While many academic manuscripts only report the total score, it is recommended that at least the second order factor be reported to account for its individual contribution to the relation being tested (PATTON et al., 1995).

The results can range from 30 (thirty) to 120 (one hundred and twenty) points. For the case of 30 (thirty) points, the respondent that, under normal questions, opts for the alternative "rarely or never" and, in the reverse questions, opts for the alternative "often/ always" will receive 1 (one) point per question. For the case of 120 (one hundred and twenty) points, the respondent that chooses the reverse alternative to the previous case will thereby receive 4 (four) points per question.

For the analysis of impulsiveness, the results considering the less impulsive concern those who approached 30 (thirty), and the most impulsive, those who neared 120 (one hundred and twenty) points. In this research, volunteers who scored in the first quartile were considered less impulsive, and the ones located in the third quartile, more impulsive (i.e., the sample's extremes).

In a second stage of the research, data were tabulated by adding the score obtained in the TAPMIL test and scores from the Air Instruction Squadron (EIA), where cadets receive practical flight instructions. It is worth remembering that the TAPMIL test assesses six factors, having been considered for this study only the multitasking capacity factor.

Armed with the information, descriptive analyzes were carried out (average, standard deviation, variation, maximum amount, minimum amount, extent, among others). In addition, the coefficient of variation of the variables under study was verified.

With data grouped in pairs, the correlation coefficient was verified.

Next, in topic 4 , tables 1 to 7 , results are presented.

\section{RESULTS}

\subsection{Descriptive analysis of tests TMT and BIS}

Table 1 - TMT.

\begin{tabular}{cc}
\hline & TMT \\
\hline Average & 93,53333 \\
Standard error & 5,495232 \\
Median & 88 \\
Mode & 136 \\
Standard deviation & 36,86314 \\
Sample variation & 1358,891 \\
Kurtosis & 0,162757 \\
Asymmetry & 0,73699 \\
Interval & 158 \\
Minimum amount & 40 \\
Maximum amount & 198 \\
Sum & 4209 \\
Count & 45 \\
\hline
\end{tabular}

Reference: The author. 
Table 2 - BIS.

\begin{tabular}{cc}
\hline & BIS \\
\hline Average & 61,26667 \\
Standard error & 1,664362 \\
Median & 61 \\
Mode & 66 \\
Standard deviation & 11,16488 \\
Sample variation & 124,6545 \\
Kurtosis & $-0,53319$ \\
Asymmetry & 0,236712 \\
Interval & 45 \\
Minimum amount & 42 \\
Maximum amount & 87 \\
Sum & 2757 \\
Count & 45 \\
\hline
\end{tabular}

Reference: The author.

The BIS variation coefficient is $18.22 \%$ and TMT's is $39.41 \%$, which means that, below $30 \%$, the sample is regarded as homogeneous, and above this percentage, it is considered heterogeneous.

Table 3 - TAPMIL.

\begin{tabular}{cc}
\hline & TAPMIL \\
\hline Average & 111,0667 \\
Standard error & 2,490061 \\
Median & 109 \\
Mode & 98 \\
Standard deviation & 16,70384 \\
Sample variation & 279,0182 \\
Kurtosis & $-0,00887$ \\
Asymmetry & $-0,12804$ \\
Interval & 82 \\
Minimum amount & 64 \\
Maximum amount & 146 \\
Sum & 4998 \\
Count & 45 \\
\hline
\end{tabular}

Reference: The author.
Table 4 - EIA

\begin{tabular}{cc}
\hline & EIA \\
\hline Average & 4,374933 \\
Standard error & 0,029532 \\
Median & 4,343 \\
Mode & 4,257 \\
Standard deviation & 0,198105 \\
Sample variation & 0,039245 \\
Kurtosis & $-0,42877$ \\
Asymmetry & 0,516116 \\
Interval & 0,8 \\
Minimum amount & 4,029 \\
Maximum amount & 4,829 \\
Sum & 196,872 \\
Count & 45
\end{tabular}

Reference: The author.

The TAPMIL variation coefficient is $15.04 \%$ and EIA's, 4.53\%, both below 30\%, which means data homogeneity.

\subsection{Correlation coefficient}

This subtopic shows the coefficients of the TMT and TAPMIL tests and the EIA score in relation to the BIS test (impulsiveness).

Table 5 - Correlation 1.

\begin{tabular}{ccc}
\hline \multicolumn{3}{c}{ Correlation 1 } \\
\hline BIS & BIS & TMT \\
TMT & 1 & 1 \\
\hline Reference: The author. & &
\end{tabular}

Table 6 - Correlation 2.

\begin{tabular}{ccc}
\hline \multicolumn{3}{c}{ Correlation 2 } \\
\hline BIS & BIS & TAPMIL \\
TAPMIL & 1 & 1 \\
\hline
\end{tabular}

Reference: The author.

Table 7 - Correlation 3.

\begin{tabular}{ccc}
\hline \multicolumn{3}{c}{ Correlation 3 } \\
\hline BIS & BIS & EIA \\
EIA & 1 & 1 \\
\hline Reference: The author & $-0,005561046$ &
\end{tabular}

Reference: The author. 
There is no correlation of impulsiveness with other test sand also their relation ship is reversed. That is, the conclusion reached from the analysis of data from TMT, BIS-11 and TAPMIL tests and EIA scores is that the most skilled cadets in managing multiple tasks, as well as the most skilled at flying, are not those who show the highest impulsiveness.

This conclusion is quite auspicious, because impulsiveness is a very undesirable characteristic in the military, especially in the case of military aviation.

\section{CLOSING REMARKS}

This study came from the interest in verifying whether the impulsiveness variable interferes with multitasking and whether it affects performance in flying. Research by Araújo et al. (2009) concluded that impulsiveness is associated with risky behavior in traffic, speeding for thrills and offenses.

From what has been proposed for this study, there was no correlation between the impulsiveness variable and multitasking, or an association between impulsiveness and performance in flying.

\section{REFERENCES}

ARAÚJO, M. M.; MALLOY-DINIZ, L. F.; ROCHA, F. L. Impulsividade e acidentes de trânsito. Revista de Psiquiatria Clínica, v. 36, n. 2, p. 60-68, 2009.

BAZERMAN, M. H. Judgment in managerial decision making. 6th ed. Hoboken: J. Wiley \& Sons, 2006.

COSTA, M. P. Estudo de normatização e validação do teste de aptidão para a pilotagem militar. 2010. Dissertação (Mestrado) - Instituto de Psicologia, Universidade de São Paulo, 2010.

DAVEL, E.; VERGARA, S. C. (Org.). Gestão com pessoas e subjetividade. São Paulo: Atlas, 2001.

FÁVERO, L. P. et al. Análise de Dados: modelagem multivariada para tomada de decisões. Rio de Janeiro: Elsevier, 2009.

KLEIN, G. Sources of power: how people make decisions. Cambridge: MIT, 2000.

MALLOY-DINIZ, L. F. et al. Impulsiveness scale (BIS-11) para aplicação em adultos brasileiros.
Jornal Brasileiro de Psiquiatria, Rio de Janeiro, v. 59, n. 2, p. 99-105, 2010.

HERCULANO-HOUZEL, S. O cérebro nosso de cada dia. Rio de Janeiro: FAPERJ: CNPQ, 2000. Disponível em:< http://www.cerebronosso.bio.br/guiabsico-de-neurocincia>. Acesso em: 5 mar 2014.

PATTON, J. H.; STANFORD, M. S.; BARRATT, E.S. BIS-11 instrument reference. Factor structure of the Barratt impulsiveness scale. Journal of Clinical Psychology, v. 51, n. 6, p. 768-774. Disponível em: <http://www.impulsivity.org/measurement/bis11>. Acesso em: 25 mar. 2014.

SANBONMATSU, D. M et al. Who multi-tasks and why? Multi-tasking ability, perceived multi-tasking ability, impulsivity, and sensation seeking. PSO ONE, v. 8, n. 1, jan. 2013.

SILVA, L. M. A.; LUCAS, L. A.; COSTA, M. P. Analysis of decision making processo flight instructors at the Brazilian Air Force Academy. In: INTERNATIONAL CONFERENCE ON NATURALISTIC DECISION MAKING, 9., 2009, London. Proceedings of ... London: [s .n.], 2009. 